\title{
Is the Regulation of Railroad Crossings a Municipal Affair?
}

I N THE case of City of Los Angeles v. Central Trust Co., ${ }^{1}$ the Supreme Court of California recently held that the City of Los Angeles, by charter provisions, had the power to open streets across a railroad, and to regulate the manner in which the crossing should be maintained, guarded and protected by the railroad company and by the municipal authorities. They held that this was, under the constitution, ${ }^{2}$ a municipal affair, and consequently paramount to general laws which would have operated except for the charter provisions. ${ }^{3}$ The controversy involved the question whether Section 43 of the Public Utilities Act of IgrI* controlled in the matter of railroad crossings in the City of Los Angeles. This section provides that no crossings of any railroad by a street, or of any street by a railroad, shall be made without permission of the Railroad Commission, and that the Commission shall have exclusive power to prescribe the manner, place and grade of crossings.

It seems to us that the Supreme Court was mistaken in the position it took and that the question is of so great importance, and so likely to arise again, that we venture to suggest the grounds of our view that the interpretation of the Court is erroneous. Inasmuch as the case under discussion may be upheld on other grounds, it is to be hoped that the court will, on proper occasion, set forth clearly and unmistakably its view whether the determination of the place and manner of railroad crossings is a municipal affair or a state affair.

The Public Utilities Act was not passed until December 23, I9II, taking effect on March 23, I9I2. There had been passed, however, on February 9, I9II, the Railroad Commission Act,

1 (Sept. 11, 1916), 52 Cal. Dec. 298, 159 Pac. 1169.

2 Cal. Const. Art. XI, $\$ 6$.

${ }^{3}$ Law v. San Francisco (1904), 144 Cal. 384, 391, 77 Pac. 1014; Fritz v. San Francisco (1901), 132 Cal. 373, 377, 64 Pac. 566; Byrne v. Drain (1900), 127 Cal. 663, 667, 60 Pac. 433; Barber etc. Co. v. Costa (1915), 171 Cal. 138, 152 Pac. 296.

${ }^{4}$ Cal. Stats. Spec. Sess. 1911, pp. 18, 40. 
which, by Section $15,{ }^{5}$ gave the Commission the same power over railroad crossings as section 43 of the Public Utilities Act of December 23, r9II. The Railroad Commission Act was explicity ratified and confirmed by section 22 of article XII of the constitution as amended on October ro, rgrr. Section 23 of article XII of the constitution as amended on October IO, I9II, contained a proviso saying that "this section shall not affect such powers of control over any public utility vested in any city and county or incorporated city or town," unless the municipality should vote to release its control to the Railroad Commission. Section 82 of the Public Utilities Act of December 23, I9II, followed the same wording, substituting "this act" for "this section." As section 23 of article XII was amended in November, I9I4; the proviso reads: "this section shall not affect such powers of control over public utilities as relate to the making and enforcement of local, police, sanitary, and other regulations, other than the fixing of rates, vested in any city and county or incorporated city or town," unless surrendered by the municipality. The charter of the City of Los Angeles, as amended on March 25, IgII, gave to the city the following powers: "To establish, lay out, open . . . or otherwise improve streets, lanes, alleys, boulevards, crossings, courts, and other highways and public places;" and also, "To regulate, subject to the provisions of the constitution of the State of California, the construction and operation of railroads, interurban railroads, street railways, or other means of transportation, conduits, waterworks, and works or plants for the production, transmission or distribution of gas, electricity, heat, refrigeration or power, and the works or plants of any other public service utility."?

It is our opinion (I) that the regulation of railroads, that is to say, general, commercial railroads, is a state affair and not a municipal affair; (2) that whatever jurisdiction in the matter of railroads may belong to municipalities, jurisdiction over the conditions of railroad crossings at least had at the time of the institution of proceedings in the present case, been taken away by proper legislation and vested in the Railroad Commission;

5 Cal. Stats. 1911, pp. 13, 18.

6 Cal. Stats. 1911, pp. 18, 62.

7 Cal. Stats. 1911, pp. $2061,2063$. 
and (3) that, even failing the validity of these contentions, nevertheless sections 22 and 23 of article XII of the constitution as amended in $19 x x$, gave the Railroad Commission complete and exclusive control over the conditions under which railroad crossings may be constructed.

(I) To open, lay out, and improve streets within the city, is unquestionably a municipal affair, ${ }^{8}$ as here held by the court. And there is no doubt that Los Angeles had by its charter of I889 effectively claimed this power. ${ }^{9}$ But it is essentially a different question whether the determination of the place and manner in which a street shall cross a commercial railroad track is or can be under our constitution other than a state affair under the control of the legislature. We believe that the authority which a city has over railroads arises from the provisions of section II of article XI of the constitution rather than from the provisions of section 6 of article XI. Section 6, before November 3, 19I4, provided that city charters, except in municipal affairs, should be subject to and controlled by general laws. Section II reads : "Any county, city, town, or township may make and enforce within its limits all such local, police, sanitary and other regulations as are not in conflict with general laws." The principle is, that if the power comes from section 6 it is then a municipal affair and the charter provision is paramount to general laws on the same subject. But a power which is exercised under section II is subject to displacement by the enactment of a general law on the same subject, no matter what the charter may say. We will not go so far as to say that no police or sanitary regulations may not be municipal functions and beyond control by the legislature; but we believe that the purpose of this section is to allow municipalities authority to regulate their local police and sanitary situation in matters which only incidentally affect police questions of general state concern and only so long as the state legislature refrains from acting thereon.

The charter provision of Los Angeles mainly relied on to give the city power to regulate the place and manner of street

8 Sinton v. Ashbury (1871), 41 Cal. 525, 531 ; People v. Holladay (1892), 93 Cal. 241, 248, 29 Pac. 54, 27 Am. St. Rep. 186; Hellman v. Shoulters (1896), 114 Cal. 136, 149, 44 Pac. 915, 45 Pac. 1057; Byrne v. Drain, supra, n. 3.

${ }^{\circ}$ Cal. Stats, 1889 , p. 457. 
and railroad crossings is in these words: "To regulate, subject to the provisions of the constitution of the State of California, the construction and operation of railroads .... and the works or plants of any other public utility. ${ }^{10}$ We cannot convince ourselves that all of the powers enumerated in this provision are strictly municipal functions. In particular, we do not believe that the "regulation of the construction and operation of railroads" is a municipal function. On the contrary, we believe it is essentially a state affair and under the control of the legislature. We believe that this must necessarily be so, apart from any constitutional provision on the subject, and that the court, if looking squarely at the question, would so declare. Such a view does not oust the city of all jurisdiction, but such jurisdiction as it has is probably only concurrent in its nature, and subject to be superseded by general laws. The local police power which a municipality may exercise over railroads is derived from section II of article XI, namely, "to make and enforce all such local, police, and sanitary regulations as are not in conflict with general laws." The situation is much like that between a state in the exercise of its police power and the general government in the exercise, say, of its power over interstate commerce. The state, in the absence of congressional legislation, may do many things which incidentally affect interstate railroads, such as regulate the speed of trains and stopping places, but its regulations must yield whenever they conflict with the powers belonging to Congress. ${ }^{11}$ Here the city may exercise its regulatory control over railroads subject to any general laws. Therefore, we believe that the amendment to the Los Angeles charter in I9I I giving the city power to "regulate, subject to the provisions of the Constitution of the State of California, the construction and operation of railroads," was a power or mere local police regulation, already authorized by section II of article XI, and defeasible by general legislation. Section I7 of article XII of the constitution has always declared that "all railroad, canal and other transportation companies are common carriers, and subject to legislative control." And the Supreme Court has said: "It is universally recognized that the state in its sovereigu capacity has the original

10 Cal. Stats. 1911, p. 2063.

11 Adams Express Co. v. Kentucky (1909), 214 U. S. 218, 53 L. Ed. 972, 29 Sup Ct. Rep. 633. 
right to control all public streets and highways, and that except in so far as that control is relinquished to municipalities by the state, either by provision of the state constitution, or by legislative act not inconsistent with the constitution, it remains with the state legislature to be exercised in any manner not prohibited by the state constitution." 12

If the state has a supreme right over streets and highways in general, how much more obvious is its jurisdiction over railroads, whose franchises are derived from legislative authority, ${ }^{13}$ and which operate through several counties and perhaps through the whole length of the state. Just because the proposition is so obvious, is why we are perhaps lacking in direct judicial authority thereon.

(2) In the second place, it seems to us, from an examination of the law, that whatever jurisdiction the city might otherwise have exercised over the place and manner of railroad crossings had, at the time of the institution of proceedings in the present case, been superseded by appropriate general laws. Under section 6 of article XI of the constitution as it has existed since November 3 , 1914, it would not be necessary for a new city charter or a properly amended charter to make claim of any specific power as a municipal affair; all affairs that are municipal belong to it as of course. But between November 3, 1896, and November 3, 1914, it was necessary for a city to enumerate the municipal functions which it wished to exercise in order to be exempt from general laws. ${ }^{14}$ And, of course, both before November 3, I9I4, and since then, a function, even though claimed in the charter as municipal, would not be held within the competence of the city, if in fact it be a state affair and not a municipal one.

The court says that the charter of Los Angeles as amended in I9I I contained a clause giving to the city power "to regulate, subject to the provisions of the Constitution of the State of California, the construction and operation of railroads, and other public utilities in their operations within the city. (Sec. 2, subd. 30.)" And then the court says further: "The charter of 1889 and

12 Western Union Tel. Co. v. Hopkins (1911), 160 Cal. 106, 118, 116 Pac. 557.

13 San Francisco \& San Mateo Elec. Ry. Co. v. Scott (1904), 142 Cal. 222, $75 \mathrm{Pac} .575$.

14 Fragley v. Phelan (1899), 126 Cal. 383, 58 Pac. 923. 
the amendments of 1905 and 1909 to section 2 gave to the city similar powers. (Stats. I889, 457; Stats. I905, 994; Stats. I909, r29r.)"

We submit that the court is mistaken in saying that the charter of 1889 and the amendments of 1905 and I909 had similar provisions to that of IgIr. We believe that the amendment of I9II giving the city power of regulation over the construction and operation of railroads was new. The charter of 1889 had no provision mentioning railroads. Subdivisions 7 and 8 of section 2 read as follows:

" 7 . To provide for supplying the city and its inhabitants with water or gas, or either, or other means of heat and illumination.

"8. To lay out, open, extend, widen, improve, or vacate, pave, and repave streets and alleys, sidewalks and crossings, and other highways." 15

In I905 subdivision 7 of section 2 was amended to read as follows :

"(7) To provide for supplying the city and its inhabitants with water and gas, or either, or with other means of heat, illumination or power; and to acquire or construct and to lease or operate, and to regulate the construction or operation of conduits or of railroads or other means of transit or transportation, and of plants and equipments for the production or transmission of gas, electricity, heat, refrigeration or power, in any of their forms, by pipes, wires or other means; and to incur a bonded indebtedness for any of such purposes, provided the question of the issue of bonds therefor shall first be submitted to the qualified electors of the city at a special or general election, and that three-fifths of the votes cast on the question of said issue of bonds shall have been cast in favor thereof." 16

In rgog, subdivision 7 was amended by inserting the word "electricity" after the first mention of water and gas, and by changing the vote necessary for issuing bonds from three-fifths to two-thirds of the votes cast. Another subdivision mentioning railroads, numbered " $(7 \mathrm{~b})$ " was added, as follows:

" $(7 \mathrm{~b})$. To acquire or build and operate railroads and interurban railroads from any point within the city limits, to any place or places within Los Angeles county and located 
on the ocean, or any inlet thereof, for the purpose of transporting passengers or freight between the city and the ocean, and to fix and collect charges therefor."17

Superficially read, the amendment of I905 would seem to give a general power to regulate railroads, but further consideration seems to lead to the obvious conclusion that the amendments of 1905 and 1909 were intended to invest the city with authority to construct and maintain municipally owned railroads and other utilities. It is furthermore manifest that the purpose in subdivision 7 was to authorize intramural railroads only, for subdivision $7 \mathrm{~b}$ was added in 1909 in order to authorize interurban and tide-water railroads. Los Angeles, along with some other cities in the state, was leading the way towards municipally owned and operated utilities. And this tendency found expression in the constitution as amended in IgII, by declaring that "any municipal corporation may establish and operate public works for supplying its inhabitants with light, water, power, heat, transportation, telephone service or other means of communication. ${ }^{18}$ The constitution here indicates the kind of public utilities which it is proper for municipalities to control, and, hence, control over which is properly a municipal affair. For what the city is here authorized to do for itself, it might under proper charter provision empower private enterprise to do. But while "transportation" is here authorized, it is transportation within the city by means of street railways and not transportation into and out of the city, whether by railroad or otherwise. Further, in interpreting subdivision 7, given above, as amended in 1905, it is well to remember these words of our Supreme Court: "It is thoroughly settled that language purporting to define the powers of a municipal corporation is to be strictly construed, and that any 'fair, reasonable doubt concerning the existence of the power is resolved by the courts against the corporation, and the power is denied.' (I Dillon on Municipal Corporations, § 89.)"'10

Now, proceedings in the case under discussion, to condemn property of the railroad company in order to open a street across their right of way, were begun December 26, I9II. Action in the superior court was begun April I8, I9I2.

17 Cal. Stats. 1909, p. 1291.

18 Cal. Const. Art. XI, \&19.

19 Oro Electric Corp. v. Railroad Commission (1915), 169 Cal. 466, 477, 147 Pac. 118. 
On February Io, I9II, the Railroad Commission Act was passed, conferring upon the Railroad Commission exclusive power over railroad crossings, whether of one railroad by another railroad, or of a railroad by a public road or highway; such power including the point of crossing, and separating, changing or abolishing crossings. ${ }^{20}$ Section 22 of article XII of the constitution, as amended October Io, I9II, declared that the provisions of the Railroad Commission Act of February Io, I9II, should be construed with reference to that section and any other constitutional provision becoming concurrently operative therewith. The act of February Io, I9II, was thus given constitutional sanction, and the provision above referred to was later made more explicit by section $43 \mathrm{~b}$ of the Public Utilities Act of December 23, I9II, which defined what was meant by railroad crossings, saying that the Railroad Commission should have exclusive authority over "each crossing of one railroad by another railroad or street railroad, and of a street railroad by a railroad, and of each crossing of a public road or highway by a railroad or street railroad and of a street by a railroad or vice versa."21

Thus, by operation of the general law of February Io, I9II, which was in effect made part of the constitution by vote of the people on October IO, I9II, control over crossings between streets and railroads had been vested in the Railroad Commission. Now, of course, if the matter of railroad crossings within city limits is wholly a municipal affair, the state legislature could not permanently bar chartered cities from exercising their rightful functions; but the presumption is at least just as strong that the legislature in enacting section I5 of the Act of February, I9Ir, was within its rights, when it explicitely charged the Railroad Commission with exclusive control over railroad crossings, as that the people of Los Angeles were within their rights, when they claimed control over railroads as a municipal function, if indeed that was their intention, which we doubt. The general law of February, I9r $r$, and the Los Angeles charter provisions of October, IgII, must either be in accord or in conflict. We are unable to see any conflict. There is no reason to suppose that the power distinctly vested in the Railroad Commission by the Act of

${ }^{20}$ Cal. Stats. 1911 , p. 18.

21 Cal. Stats. Extra Session 1911, p. 40. 
February was withdrawn therefrom, as to Los Angeles, by the charter amendment of March. And the wording of the charter amendment is in further support of the view that no conflict was thereby caused. Every consideration leads to the conclusion that the charter amendment "to regulate, subject to the provisions of the Constitution of the State of California, the construction and operation of railroads," was but a specification of the powers authorized by section II of article XI of the constitution, namely, local police control. The legislature, by the act of February, I9II, evidently thought that police control of railroads by local governments should, so far as the character of railroad crossings was concerned, be withdrawn from local control and be given over to general state supervision. Los Angeles lost nothing that was peculiarly municipal; at most, what she lost was the local administration of a state affair.

As persuasive argument that the city did not have complete control over railroad crossings by force of the charter amendment of March 25, I9II, is a charter amendment of January I7, I9I7, adding a new subdivision, which gives the city power "to require or provide for the elevation or depression, in whole or part, of railway or railroad tracks." 22 This argues that the people of Los Angeles did not conceive that the city already had control over railroad crossings. Of course, this amendment of 1917 is, in our view of the law, entirely ineffectual so far as it may purport to cover subjects embraced in the Railroad Commission Act of February, I9II; and, so far as it may intend to specify a municipal affair, it was quite unnecessary, for at the same time an amendment was adopted and ratified, which gives to the City of Los Angeles the control over all municipal affairs contemplated by section 6 of article XI of the constitution as amended on November 3, I9I4. This comprehensive amendment of the Los Angeles charter reads: "To make and enforce all laws and regulations in respect to municipal affairs, subject only to the restrictions and limitations provided in this charter." ${ }^{23}$

22 Cal. Legislature, 1917, Assembly Concurrent Resolution No. 3.

${ }^{23} \mathrm{It}$ is astonishing that other cities in the state have not pursued the course now adopted by Los Angeles of securing by a two or three line amendment all the privileges afforded by the amendment of section 6 of article XI of the constitution as adopted on November 3,1914 . All municipal affairs now belong to chartered cities by force of section 6 . All 
(3) In the third place, we believe that sections 22 and 23 of article XII of the constitution as amended in IgII invested the Railroad Commission with exclusive power over the place and manner of railroad crossings.

We have seen that the Railroad Commission Act of February, I9II, in section I5, invested the Railroad Commission with "exclusive power to determine and prescribe" every condition pertaining to the crossings between railroads and highways. And this act was ratified by the constitutional amendment of section 22 of article XII on October IO, I9II. Section 22 further declared that no provision of the constitution should be construed as a limitation upon the authority of the legislature to confer upon the commission "additional powers," an authority declared to be plenary and unlimited by any provision of the constitution. The Supreme Court has held that this empowered the legislature to grant to the Commission any power which is "germane or cognate to the purposes for which the Railroad Commission was created."24 Now, indubitably, it is at least germane or cognate to the purposes for which the Commission was created to empower it to regulate railroad crossings. Therefore, section I5 of the Railroad Commission Act of February, I9II, so investing the Commission and thus ratified by the Constitution, might even be said to control and displace so far as it goes the municipal affairs clause of section 6 of article XI. If therefore the regulation of state railway systems within a city might be regarded as a municipal affair, it may well be admitted that the legislature through its "plenary and unlimited" authority could declare in whatever particulars it chose that such regulation should cease to be under the exclusive jurisdiction of the city.

Furthermore, section 22, by its adoption of the Railroad Commission Act, had, as to all the matters contained in that act, removed the exemption of section 23, reserving to cities control of public utilities already vested in them. This is made plainer by the concluding sentence of section 23; to-wit: "Nothing in this section shall be construed as a limitation upon any power con-

police powers exercisable by a city are expressly granted by section 11 . Under these two comprehensive grants, municipal charters may be made very brief.

${ }_{24}$ Pacific Tel. \& Tel. Co. v. Eshleman (1913), 166 Cal. 640, 137 Pac. 1119,50 L. R. A. (N. S.) 652. 
ferred upon the Railroad Commission by any provision of this Constitution now existing or adopted concurrently herewith." The power over railroad crossings had been clearly and fully given to the Commission and could not be withdrawn by any general exemptions or reservations.

Finally, the proviso in section 23 , reserving to cities such control over public utilities as they chose to retain, said that "this section," that is section 23, should not affect such control. Now section 23 deals with the regulation of public utilities generally in their relation to the Railroad Commission, while section 22 deals with the organization of the Railroad Cominission and its powers over railroads and other transportation companies. It is section 22 that incorporates the Railroad Cornmission Act of February 9, IgIr, which, among other things, gave to the Commission exclusive control over the conditions of railroad crossings. So far then as the constitution is concerned, there is no reservation made to municipalities of control over the conditions under which railroad crossings may be constructed. Again, by amendment in November, 1914, the meaning of the reservation was made plainer, by saymg that the section should not affect such powers of control over public utilities "as relate to the making and enforcement of local, police, sanitary, and other regulations." As is obvious, the phraseology is peculiar and is identical with the well-adjudicated phraseology used in section II of article XI. This last mentioned section grants to local communities power to make such regulations only so long as no general law exists. The conclusion is inevitable that the exemption was susceptible of removal by general law.

William Carey Jones.

Berkeley, California. 